\title{
HOW CAN EXPERIMENTS WITH YEAST GENETICS HELP MAKE THE PERFECT PINT?
}

MOLECULAR BIOLOGY DEPENDS ON LABORATORY EXPERIMENTS TO UNCOVER THE SECRETS OF ORGANISMS AT THE MOLECULAR LEVEL. DESPITE BEING A RELATIVELY YOUNG FIELD, IT BRINGS WITH IT A HUGE ARRAY OF POSSIBILITIES FOR BETTER UNDERSTANDING THE WORLD AND FOR APPLICATIONS TO SOCIETY. ONE SUCH APPLICATION IS THE GENETIC MODIFICATION OF BREWER'S YEAST TO IMPROVE THE FINAL PRODUCT: A COOL GLASS OF ALE OR STOUT. DR MICHAEL WOLYNIAK OF HAMPDEN-SYDNEY COLLEGE CHALLENGES HIS STUDENTS TO INVESTIGATE THE YEAST GENOME TO DEVELOP THEIR OWN PRACTICAL SKILLS WHILST SIMULTANEOUSLY BENEFITING THE BREWERY ROUND THE CORNER

\section{TALK LIKE A MOLECULAR BIOLOGIST}

DNA - an organism's genetic 'blueprint' that is inherited from its parents, and is present within every cell

ENZYME - a biological molecule that facilitates chemical reactions in cells

EUKARYOTE - an organism whose cell/s has genetic material contained within the nucleus

FLOCCULATION - the process by which particles (e.g. cells) clump together
GENE DISRUPTION - 'breaking' a gene, such as by deleting part of it or inserting additional DNA, so it is no longer recognised as a gene

GENOME - the complete set of genetic material in a cell

MODEL ORGANISM - a species that has been widely studied to understand biology that can then be applied to other organisms.

RNA - a molecule used in the expression of genes
SACCHAROMYCES CEREVISIAE (S. CEREVISIAE) - the species of yeast most often used in molecular biology

TRANSCRIPTION - the first step of gene expression, when a gene's DNA sequence is copied to make an RNA molecule

TRANSLATION - the step in gene expression where ribosomes synthesise a protein by reading an RNA molecule
A big challenge for teaching science is introducing meaningful research into the curriculum. Learning the theories of science is all well and good, but a full appreciation of any area of science involves doing it yourself. Investing the time and resources necessary for these practical lessons to be a fulfilling experience is not always easy, but $\mathrm{Dr}$ Mike Wolyniak has found a way. He and his department at Hampden-Sydney College, based in Virginia in the USA, teamed up with Three Roads Brewing, a microbrewery in a nearby town, to improve the production process of four beers by altering the yeast itself.

This course-based research experience (CURE for short) involved getting students participating in 'improving' strains of yeast through modifications to their genome. The brewmaster wanted changes to four different strains of yeast - for instance, they wanted some strains of yeast to stop clumping together (flocculating), and others to have a modified fermentation process to produce different quantities of alcohol. This could lead to improved end products for the brewery, including beers with added or reduced alcohol content, and distinct flavours.

THE TASK

When the project began, the students had several steps ahead of them:

- Introduction. What end results was the brewmaster seeking, and how could molecular biology assist in making these a reality?
- Research. Using online resources to find out which yeast gene(s) to target for manipulation.

- Proposal. Planning how to undertake the genetic manipulation task, and how to test for success.

- Genetic manipulation. Using gene disruption or other techniques to change the yeast genome.

- Experimentation. Testing that yeast cells have been genetically edited, and that they do what they should.

- Dissemination. Presenting their results to colleagues and the brewmaster, and thinking about next steps. 

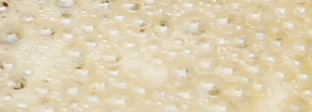

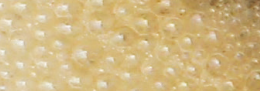
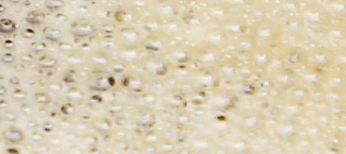

\section{THE WONDERS OF YEAST}

Yeast are single-celled organisms that belong to the fungus kingdom. They are also eukaryotic. This means that, like us and unlike bacteria, their genome is enclosed within a nucleus. All these properties make them very useful to scientists because, as well as being easy to grow and genetically manipulate, they share fundamental biomolecular properties with other eukaryotes, such as humans. This means that studying the properties of yeast gives us an insight into how our own biology works, without having to perform complex biomedical experiments using humans or other multicellular organisms.

The students used four strains of

Saccharomyces cerevisiae, the species of yeast most familiar to bakers, brewers and geneticists alike. As this 'model organism' has one of the most studied genomes in the world, the students could draw on an extensive online knowledge bank. Its genetic map is available online, where anyone can freely discover which genes do what and how they interact with each other.

Of course, there are still many knowledge gaps, since even the humble yeast has an immensely complex genetic profile with a near-infinite number of possible genetic interactions, but there is more than enough existing information for students to think about how to improve the brewery's products. Their findings could even potentially add to this knowledge bank, providing useful information for future researchers.

\section{GENETIC MODIFICATION}

The core principle of genetics is that certain genetic characteristics (genotypes) will lead to certain physical characteristics (phenotypes) in a cell. The way that any particular gene is expressed in yeast goes something like this:

- Enzymes in the nucleus copy the gene's DNA sequence to make a complementary RNA molecule. This is known as transcription.

- The RNA strand moves to the cell's ribosomes, which read the RNA sequence to make a protein. This is known as translation.

- The presence of the protein leads to a particular characteristic in the cell: its phenotype.

At its simplest, gene disruption essentially stops this process in its tracks by adding DNA that interferes with the gene itself, making it unreadable by the enzymes in the nucleus. There are also various other methods of genetic modification, such as inserting other genes, or adding genes for proteins that suppress the target gene or the protein it produces. Methods are becoming increasingly sophisticated year on year, allowing scientists to undertake ever-more complex genetic modifications.

The students were able to use online databases to find which genes led to flocculation, for instance, and then set about finding ways to switch them off. This 'disruption' process involves making millions of copies of a particular DNA fragment and flooding the yeast culture with them in the hope that some will be taken up and disrupt the flocculation gene.

The big question, though, is what do the students get out of this "learning by doing' project? Well, this student-driven experiment challenged students by giving them freedom! "My job is to help the students to overcome their fear of failure or not finding interesting results. This is reflective of research in general," Mike explains. "The authenticity of the project got the students excited to do the work and to spend time in the lab. The project was real to them and had very specific 'real world' applications."

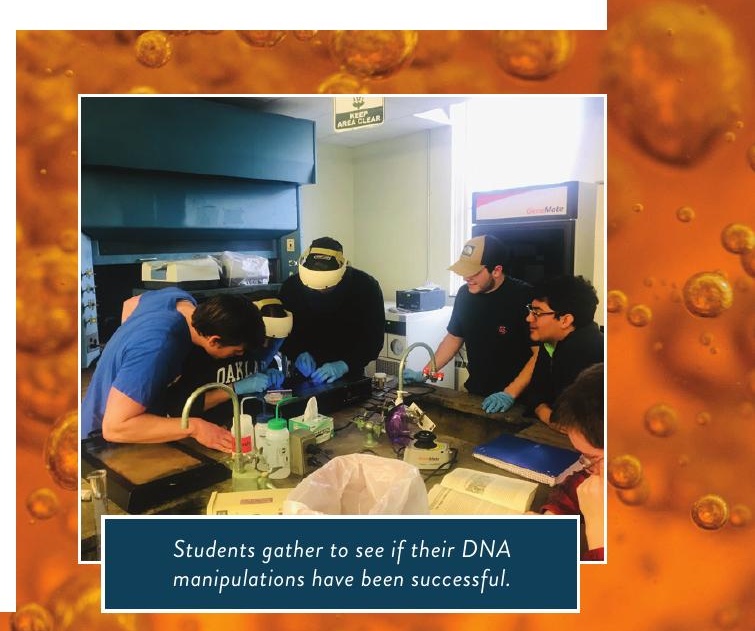

Mike led a course-based research experience (CURE), facilitating student-led experiments in yeast genetics for a local brewery. 


\section{ABOUT \\ MOLECULAR BIOLOGY}

WHAT IS MOLECULAR BIOLOGY?

Molecular biology investigates how living organisms function at the molecular level.

This might involve working out how proteins operate, investigating which molecules drive respiration, or uncovering how cells divide. It is closely related to biochemistry, which focuses on the chemical processes related to living organisms. Both these fields lean heavily on genetics, which investigates how particular DNA sequences (genes) are expressed in organisms. All are dynamic fields of science, with major breakthroughs every few years.

\section{A RAPIDLY GROWING FIELD}

These scientific fields are relatively new. The techniques needed to observe organisms at the molecular level have only been around since the mid-20th century; DNA was only discovered in 1953, and only through technological advances. Since then, the field has come on in leaps and bounds, every successive generation bringing about new major breakthroughs. In the past 60 years, we have seen the advent of societychanging procedures such as genetic modification, in-vitro fertilisation and cloning, to name but a few. Such techniques bring with them big questions for ethics and society, which must always be considered in scientific research.

Until relatively recently, the main challenge for molecular biology has been replicating DNA samples to get enough material to experiment with. That was until the Polymerase Chain Reaction (PCR) was honed, which now allows DNA to be replicated quickly and on a massive scale. Nowadays, there is plenty of data available, and the challenge is interpreting it through experimentation and research. "The next generation can use this data to unlock some of the great unknowns about how genes function, which could lead us to understand genetic diseases and how to treat them," says Mike.

\section{THE IMPORTANCE OF PRACTICAL EDUCATION}

So how does Mike's research, and the work of his students, fit into the picture? "My own research with a simple organism like yeast isn't going to cure any human diseases, but it can help us to better understand the fundamental processes taking place in all kinds of cells," says Mike. "Understanding these will ultimately lead to a better understanding of life processes, and potentially exciting medical breakthroughs."

Mike's work is also instrumental in ensuring the next generation of molecular biologists are primed for the scientific lifestyle. "It is really exciting to have students discover their passions through doing projects like this," he says. "In a small way, I am helping to lay the foundation for future scientists, doctors or teachers who could make critical discoveries."

Hampden-Sydney College also extends its efforts to the wider community. "We run outreach programmes at the local high school, which involve student mentoring or simple environmental research projects," says Mike. "We also try to bring several alumni back every year to talk about their careers and offer advice to interested students." Scientific communication is crucial for several reasons: it inspires new generations to enter science, and also helps connect wider society to scientific advances.

\section{HOW TO BECOME A MOLECULAR BIOLOGIST}

- For the UK, the Complete University Guide lists the University of Cambridge, the University of Oxford, Imperial College London and the University of Dundee as the top 4 universities for biological sciences (including molecular biology).

- For the USA, US News ranks Harvard University, Massachusetts Institute of Technology, Stanford University and University of California (San Francisco) as the top 4 universities for molecular biology and genetics.

- Many institutes will take on laboratory apprenticeships. These include organisations like GlaxoSmithKline.

- An average molecular biologist's salary is in the region of $\$ 80,000$ per year in the USA. Most work for research development centres, followed by universities and pharmaceutical companies.

\section{PATHWAY FROM SCHOOL TO MOLECULAR BIOLOAY}

There are a number of degrees that can ultimately lead to a career in molecular biology. As well as molecular biology itself, courses like biology, biochemistry, bell biology, microbiology and genetics all provide clear career pathways to molecular biology.

All these degrees will prefer similar A-level (or equivalent) qualifications within their entry requirements. Biology, chemistry and maths will be most desired, followed by physics. Mike also recommends considering communicationbased qualifications; in the UK, this could include subjects like English or critical thinking.

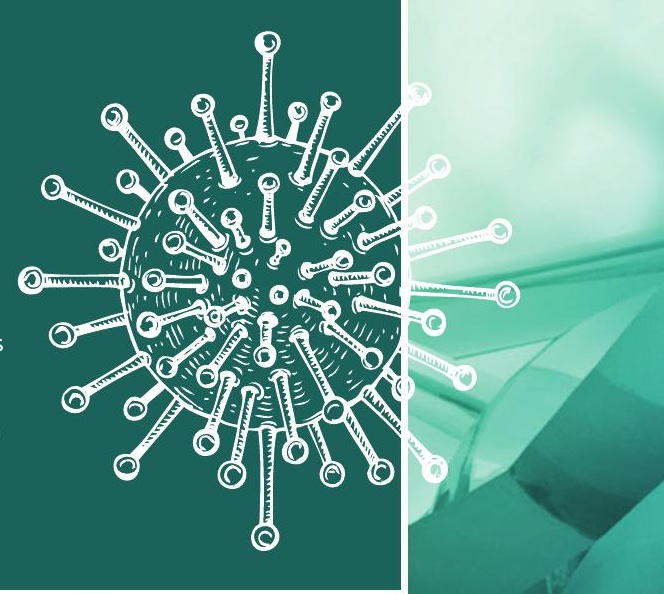




\section{HOW DID DR MIKE WOLYNIAK BECOME}

\section{A MOLECULAR BIOLOGIST?}

WHAT INTERESTS DID YOU HAVE AS A CHILD?

I was always fascinated by the natural world, and in my younger years wanted to become a zookeeper. It wasn't until later that my scientific interests turned to the microscopic! I also enjoyed music, playing the cello in the school orchestra.

HOW DO YOU MOTIVATE YOURSELF WHEN YOU FACE OBSTACLES?

The most important trait I have as a scientist is persistence. I have learned over many years that science is much more about failing than succeeding, and that success only comes after many failures. Although I don't always realise it at the time, I learn a lot from every mistake and become better at my work as a result.

\section{IF YOU HADN'T ENTERED}

ACADEMIA, WHAT WOULD YOU HAVE DONE?

My passion is teaching. If I was not in my current career, I would probably be teaching high school science, or perhaps history - my second favourite subject.

WHO HAS INSPIRED YOU IN YOUR CAREER?

I have been lucky enough to have had teachers throughout my life that taught me how to learn, be persistent, and work with others to solve problems. They inspired me to return the favour by using these skills in teaching the next generation of scientists.

HYPOTHETICALLY, WHAT WOULD BE YOUR DREAM PROJECT?

I would love to find a completely new organism and work from scratch to understand all its genes. That would provide plenty of questions for students to answer over many years and would give them the chance to produce new scientific knowledge by answering authentic unknowns.

\section{MIKE'S TOP TIPS FOR STUDENTS}

1 Don't be afraid to fail, and don't be discouraged by failure. Every scientific success is informed by failures.

2 Focus on your communication skills. Effective communication can get others excited about your work and help you get the resources to broaden your scientific horizons.

3 As well as the obvious subjects like biology and chemistry, think about taking classes in public speaking or similar disciplines in preparation for a scientific career. Many scientists have trouble communicating their results; being confident in this will help you to share your passion with any audience.

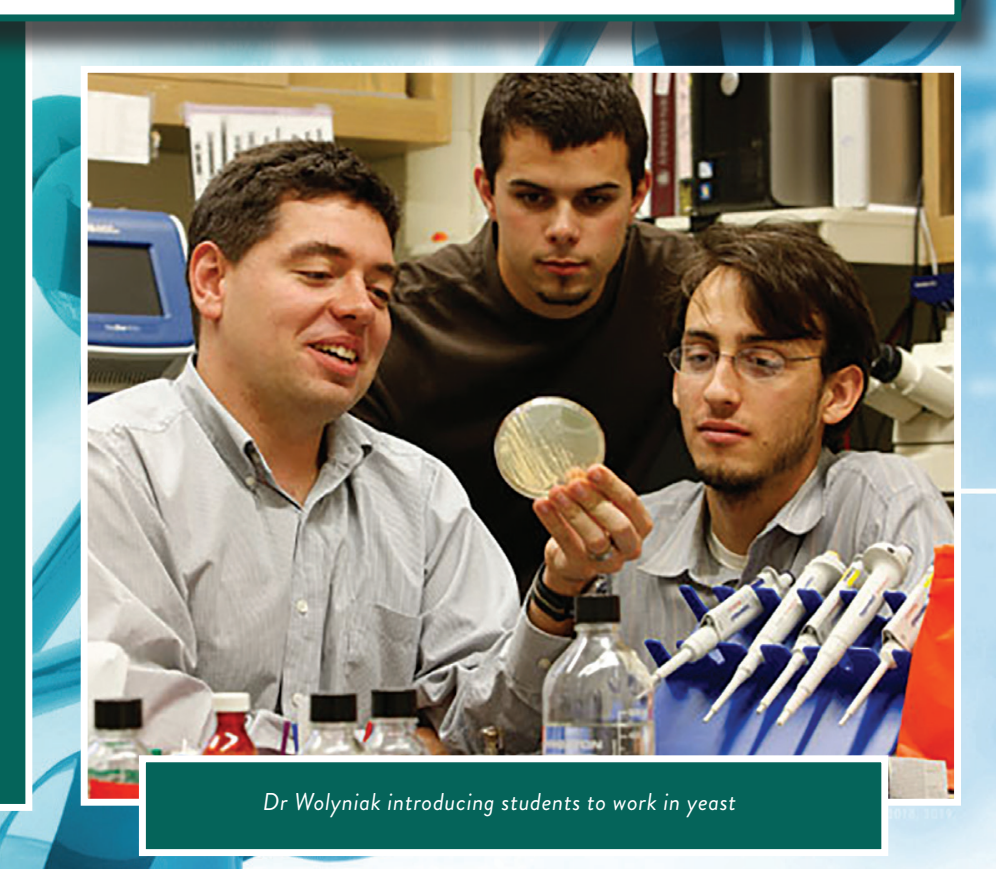

